\title{
【論文】 \\ メタンおよびアセチレンを原料としてRFプラズマ CVD 法により成膜した DLC 膜の熱伝導率 Thermal conductivity of DLC Films deposited from methane and acetylene by RF plasma enhanced CVD
}

\author{
宮井清一*、小林知洋**、寺井隆幸*
}

Seiichi Miyai, Tomohiro Kobayashi, Takayuki Terai

\begin{abstract}
RF プラズマ CVD 法によりメタン、アセチレンを原料として成膜したダイヤモンドライクカーボン (DLC)膜の熱伝導率を $3 \omega$ 法により測定した。DLC 膜の熱伝導率に影響する要因を明らかにするため、 ラマン分光測定による非晶質性、ラザフォード後方散乱/反跳原子検出法(RBS/ERDA)による膜中の水 素濃度や密度に対する熱伝導率の依存性を考察した。メタン原料では膜中の水素濃度が高く熱伝導率 が顕著な密度依存性を示さなかったが、アセチレン原料では、非晶質性が低い場合には熱伝導率が密 度と共に高くなり、非晶質性が高い場合には密度依存性を示さなかった。
\end{abstract}

The thermal conductivity of diamond-like carbon (DLC) films prepared by RF plasma enhanced CVD were investigated by $3 \omega$ method. With the results of Raman spectroscopy and Rutherford Back Scattering / Elastic Recoil Detection Analysis (RBS/ERDA), the influence of amorphousness and density on the thermal conductivity of DLC film was discussed. DLC films from methane showed no obvious dependence on density. On the other hand, depending on deposition condition, DLC films with low amorphousness from acetylene showed dependence on density, while DLC films with high amorphousness from acetylene did not show such dependence on density.

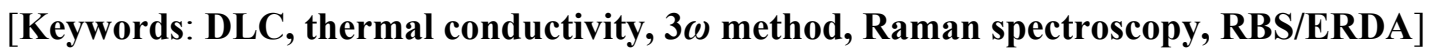

1.はじめに

ダイヤモンドライクカーボン(DLC)膜は非晶質炭素膜（a-C) あるいは非晶質炭化水素膜（a-C:H）とも呼ばれ、高硬度、低 摩擦係数、化学的安定性などにより、蒸着テープ、ハードディ スクや治工具の保護膜等に応用されている。近年では、PETボ トルのガスバリヤー膜やステントの抗血栓性向上など医療応 用の研究も盛んに行われている。DLC膜の構造、機械特性につ いては広く研究が行われているが[1]、熱云導率に関しては報告 が少ない。炭素のsp結合から成るダイヤモンドは立方晶系

* 東京大学大学院工学系研究科, $\overline{1} 113-8656$ 東京都文京区本郷 7-3-1. Grad.. School of Engineering, The University of Tokyo, 7-3-1 Hongo, Bunkyo-ku, 113-8656.

FAX: 03-5689-7349E-mail:miyais@nuclear.jp, tera@.n.tu-tokyo.ac.jp

** 理化学研究所, 下351-0198, 埼玉県和光市広沢 2-1,

The Inst. of Physical and Chemical Research,

2-1, Hirosawa, Wako-shi, Saitama, 351-0198

FAX: 048-462-4623, t-koba@riken.jp
結晶構造のフォノンによる格子振動で熱が伝わり、熱伝導率が 約 $2000 \mathrm{~W} / \mathrm{mK}$ である。炭素の $\mathrm{sp}^{2}$ 結合から成る六方晶系層状構 造のグラファイトは主に六方晶系結晶平面内のフォノンの格 子振動により熱が伝わり、熱伝導率が約 $1000 \mathrm{~W} / \mathrm{mK}$ である。一 方DLC膜は炭素と水素とから成る非晶質物質で、炭素の $\mathrm{sp}^{3}$ 結 合と $\mathrm{sp}^{2}$ 結合が混在した構造のため、結合構造の乱れや水素終 端によるフォノンの散乱により、ダイヤモンドやグラファイト に比べて報告される熱伝導率が低い[1-6]。また、DLC膜の熱伝 導率は、原料、成膜条件により報告される測定值に差があり、 その原因にはまだ不明な点が多い。Jerky Bozentaは基板に垂直 方向のDLC膜の熱伝導率は基板とDLC膜との界面に存在する 抵抗のために 0.2〜0.3W/mKであると報告した[4]。 George Chen らはFCVA法によるta-C膜の熱伝導率を光熱法で測定した結果、 4.7W/mKであると報告した[5]。Andrew J. Bullenらは熱伝導率を $3 \omega$ 法により測定した結果、遠隔プラズマ成膜法によるDLC膜 では 0.2W/mK、Filtered Arc法によるDLC膜では2.2W/mKで、 
熱伝導率は密度と共に増加寸ると報告した [6]。

本論文ではメタンおよびアセチレンを原料としてRFプラズ マCVD法により成膜したDLC膜の熱伝導率の $3 \omega$ 法による測 定結果と、ラマン分光測定による $I_{\mathrm{D}} / I_{\mathrm{G}}$ 及びFWHM $\mathrm{G}_{\mathrm{G}}$ やラザフォ 一ド後方散乱/水素前方散乱(RBS/ERDA)による水素濃度や密 度の測定結果とを関連付けて考察する。

\section{2. 実験}

\subsection{DLC 膜成膜、RBS/ERDA 及びラマン分光測定}

原料ガスとしてメタン及びアセチレンを用い、容量結合型 $\mathrm{RF}$ プラズマ CVD 法により RF 電極側に $\mathrm{Si}$ (100)基板を設置し て DLC 膜を成膜した。 RF 周波数は $13.56 \mathrm{MHz} 、 \mathrm{RF}$ パワーは 100～1500W、成膜圧力はメタンでは 1.3〜1.9Pa、アセチレン では 0.2〜0.7Pa で、基板温度制御は行わなかった。

DLC膜の水素含有量と密度はラザフォード後方散乱/反跳 原子検出法 (RBS/ERDA) により測定した。入射イオンはHe 、 入射エネルギーは $2.3 \mathrm{MeV}$ 、入射角は $75.0^{\circ}$ 、散乱角は $160^{\circ}$ 、反 跳角は30゚であつた。

DLC膜のArレーザー $(20 \mathrm{~mW}, 15 \mathrm{~A}$, 波長 $514.5 \mathrm{~nm})$ にようマ ンスペクトルを、Gaussian/Lorentzian近似で、乱れたグラファイ 卜二重結合に起因するDピーク $\left(1330 \mathrm{~cm}^{-1}\right.$ 付近 $)$ と鎖状二重結合

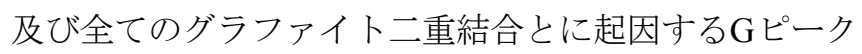

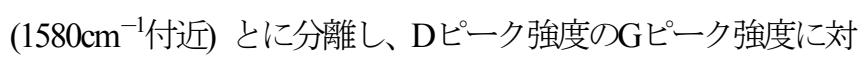
する比 $I_{\mathrm{D}} I_{\mathrm{G}}$ を算出した。DLC膜中のグラファイト結合のクラス ターサイズLaは $1 \mathrm{~nm}$ 以下で、 $I_{\mathrm{D}} I_{\mathrm{G}}$ はLaの 2 乗に比例して増加す るとされる[1]。

\section{2 熱伝導率測定}

熱伝導率は $3 \omega$ 法により測定した[8]。3 $\omega$ 法は細線状金属を 目的試料上に成膜して、その細線状金属膜に周波数 $\omega （=2 \pi f)$ の電流を流し、そのときの細線状金属膜の温度変化を測定して 熱伝導率を求める手法である[9]。細線状金属膜の温度変化を、 細線状金属膜両端間の交流電王の $3 \omega$ 成分を用いて検出するこ とから $3 \omega$ 法と呼ばれている。当初、測定対象はバルク材料だ つたが、厚さ $10 \mathrm{~nm} \sim \mu \mathrm{m}$ オーダーの薄膜試料の測定技術が報告 され[10]、半導体デバイス薄膜材料の測定に応用した報告もさ れている[11]。Fig. 2 に測定原理図を示す。膜厚 $350 \mathrm{~nm} \sim 500 \mathrm{~nm}$ の DLC 膜上のスパッタ法により形成した幅 $25 \mu \mathrm{m} \times \mathrm{E}$ 長さ $3 \mathrm{~mm}$ の $\mathrm{Al}$ 細線に異なる周波数（10～100Hz）の電流を印加し、細 線の温度上昇を測定して、(2)式以下の解析により熱伝導率を

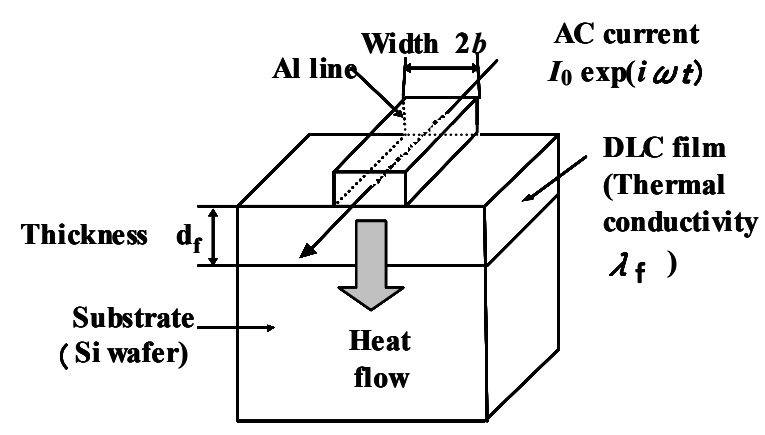

Fig.2 Schematic Figure of the Principle of $3 \omega$ Method

計算する $[8]$ 。基板(熱伝導率 $\lambda_{\mathrm{s}}$ 、熱拡散率 $D_{\mathrm{s}}$ )上に作製した薄膜 試料(熱伝導率 $\lambda_{\mathrm{f}}$ 、厚さ $\left.d_{\mathrm{f}}\right)$ )表面に細線状Al膜(幅 $2 b$ 、長さ $L$ 、 抵抗R)を作製し、この細線に電流密度 $P$ 、周波数 $\omega$ の交流電流 $I$ ${ }_{0} \exp (i \omega t)$ を印加した時の細線上Al膜の交流温度 $\Delta T(\omega)$ は式(2) で表される。

$$
\begin{aligned}
& \Delta T(\omega)=\frac{P}{\pi \lambda_{\mathrm{s}}}\left\{\frac{1}{2} \ln \left(\frac{D_{\mathrm{s}}}{b^{2}}\right)+0.923-\frac{1}{2} \ln (\omega)-\frac{i \pi}{4}\right\} \\
& +\frac{P d_{\mathrm{f}}}{2 b \lambda_{\mathrm{f}}}
\end{aligned}
$$

温度振幅の実数(in-phase)成分 $\Delta \mathrm{T}_{\mathrm{in}}$-phase $(\omega)$ 対 $\ln (\omega)$ プロッ トの傾きaから式 (3) により基板の熱伝導率が求められる。

$$
\lambda_{\mathrm{s}}=-\frac{P}{2 \pi a}
$$

基板のみの場合と薄膜試料がある場合の $\Delta T_{\text {in }}$-phase $(\omega)$ の 差 $\Delta T_{\mathrm{stf}}(\omega)-\Delta T_{\mathrm{s}}(\omega)$ から、式 (2) 第2 項から導出される式 (4)に より薄膜試料の熱伝導率が求められる。

$$
\lambda_{\mathrm{f}}=\frac{P d_{\mathrm{f}}}{2 b\left\{\Delta T_{\mathrm{s}+\mathrm{f}}(\omega)-\Delta T_{\mathrm{s}}(\omega)\right\}}
$$

以上の式で用いられた交流温度 $\Delta T$ は細線状A1膜の抵抗值の 温度变化から求められる。細線状金属膜に周波数 が印加されると細線には $2 \omega$ の電力が発生し、細線の温度が周 波数 $2 \omega$ で振動して、細線の抵抗が $R_{0} \quad\{1+\alpha \Delta T(\omega) \exp (i 2 \omega t)\}$ と周 波数 $2 \omega$ で振動する。ここで、 $\alpha$ は細線状金属膜の抵抗の温度変 化に対する係数 $\left(=1 / R_{0} \cdot \mathrm{d} R_{0} / \mathrm{d} t\right)$ である。したがって、細線上金 属膜の両端間の交流電圧 $V(t)$ は式(6)のようになる。

$$
\begin{aligned}
V(t)= & I(t) R(t) \\
& =I_{0} \exp (i \omega t) R_{0}\{1+\alpha \Delta T(\omega) \exp (i 2 \omega t)\} \\
& =I_{0} R_{0} \exp (i \omega t)+
\end{aligned}
$$


$(1 / 2) I_{0} R_{0} \alpha \Delta T(\omega) \exp (i \omega t)+$

$(1 / 2) I_{0} R_{0} \alpha \Delta T(\omega) \exp (i 3 \omega t)$

式(6)の第 1 項およひ第 2 項は周波数 $\omega の$ 成分、第 3 項が細線の 抵抗が温度変化により $2 \omega て ゙$ 振動することにより発生する周波 数 $3 \omega$ の成分である。この周波数 $3 \omega$ の成分を $V_{3 \omega} \exp (i 3 \omega t)$ と寸る と、式(7)の関係が成り立つ。

$$
\Delta T(\omega)=2 V_{3 \omega} / \alpha I_{0} R_{0}
$$

従って、、 $V_{3 \omega}$ を測定すれば細線上金属の交流温度 $\Delta T(\omega)$ が求め られる。

Fig.3 に本研究で用いた交流温度測定回路のブロックダイヤ グラムを示す。測定は 10-200Hzにおいて、2 $25^{\circ} \mathrm{C}$ 、真空中で行 った。ファンクションジェネレータにより周波数 $\omega$ の交流電流 を印加し、ブリッジ回路の非平衡電土 $v_{3 \omega}$ をロックインアンプ により測定し、式 (8) により $V_{3 \omega}$ を算出する。

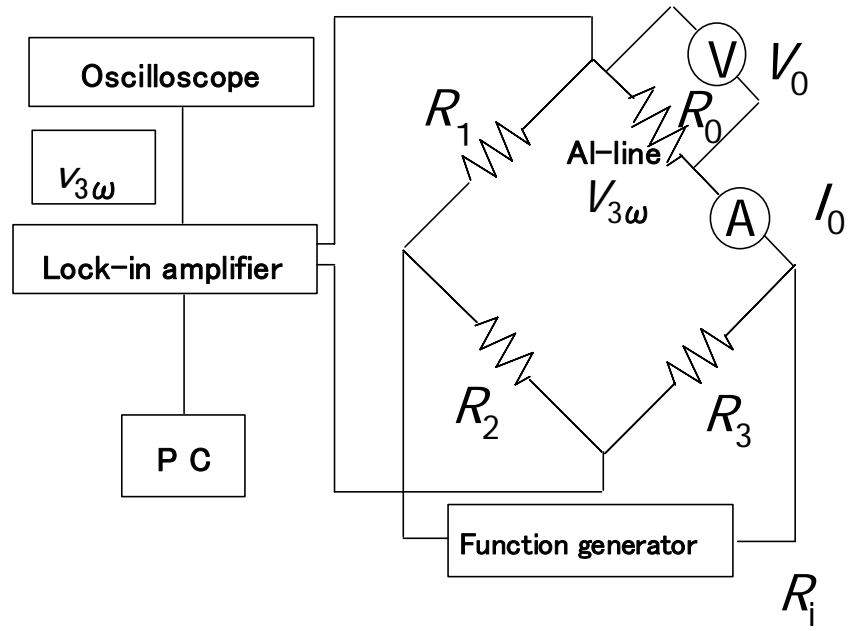

Fig.3 Block diagram of alternating current

$V_{3 \omega}=\frac{\left(R_{0}+R_{1}\right) \cdot\left(R_{2}+R_{3}\right)+R_{\mathrm{i}} \cdot\left(R_{0}+R_{1}+R_{2}+R_{3}\right)}{R_{1} \cdot\left(R_{2}+R_{3}\right)+R_{\mathrm{i}} \cdot\left(R_{1}+R_{2}\right)} \cdot v_{3 \omega}$

\section{3. 結果と考察}

\section{1 自己バイアス電圧}

本報告で用いた平行平板容量結合型 $\mathrm{RF}$ プラズマ CVD 法で は印加した RF パワーに応じて RF 電極に負の直流自己バイア ス電圧が生じる。 Fig.4 に自己バイアス電圧の RF パワー依存性 を示す。自己バイアス電圧は RF パワーと共に増加し、RF パ ワーが500Wから 1500Wにおいて、アセチレン原料がメタン原 料より約 1.2-1.3 倍高い值を示した。これはイオン化ポテンシ ヤルがアセチレンでは $11.4 \mathrm{eV}$ とメタンの $13.2 \mathrm{eV}$ より低いため

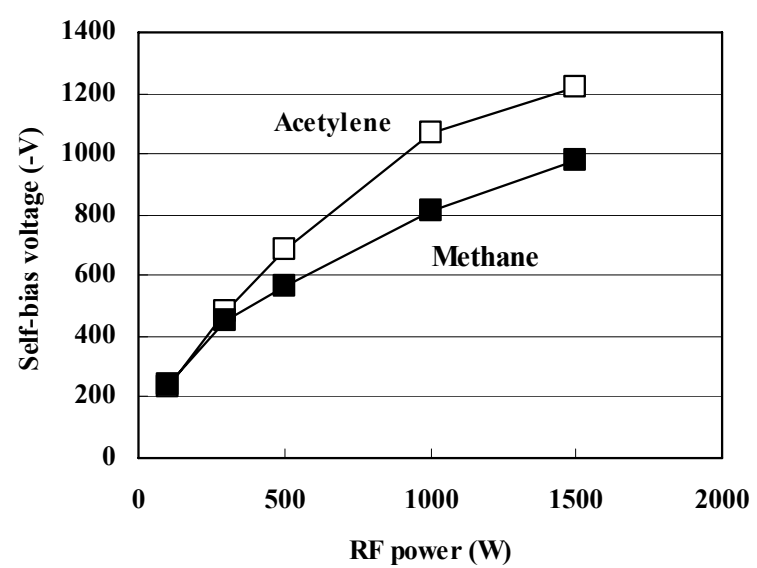

Fig.4 Dependence of Self-bias voltage on RF power

プラズマ化しやすいことによる。

負の自己バイアス電圧が高くなると RF 電極に引き付けられ る正イオンの入射エネルギーが高くなり、正イオンが基板に衝 突する際の水素脱離反応の促進、炭素と炭素の結合エネルギー 増加、炭素一炭素の結合の乱れなどにより、Si 基板上に成膜さ れるDLC 膜の膜質が変化する。

\section{2 水素濃度と密度}

ERDA により求めた DLC 膜中の水素濃度を Fig.5 に示す。メ タン、アセチレンいずれの原料も電極側に生じる自己バイアス 電圧の増加と共に膜中の水素濃度が減少した。これは自己バイ アス電圧の増加によりイオンが基板により多く引き付けられ、 基板に衝突して DLC 膜が成膜される場合の水素の脱離量が増 加することを示す。メタン原料では自己バイアス電圧と共に

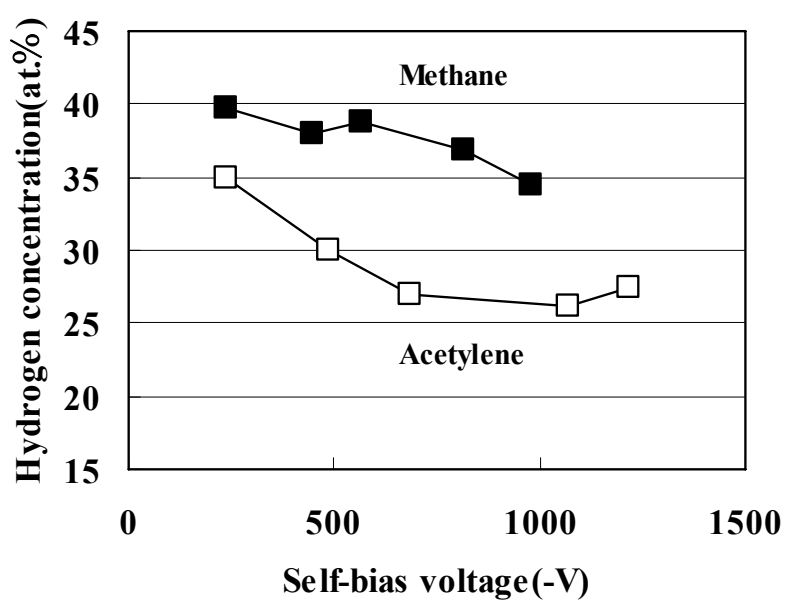

Fig. 5 Dependence of Hydrogen content on self-bias voltage 
ほぼ34at.\%まで単調に減少したが、アセチレン原料では膜中水 素濃度は自己バイアス電圧と共に26at.\%まで減少し飽和した。 Fig.6にRBS/ERDA より求めた密度のRFパワー依存性を示す。 メタン原料の場合は RF パワーと共に密度は単調に減少し、

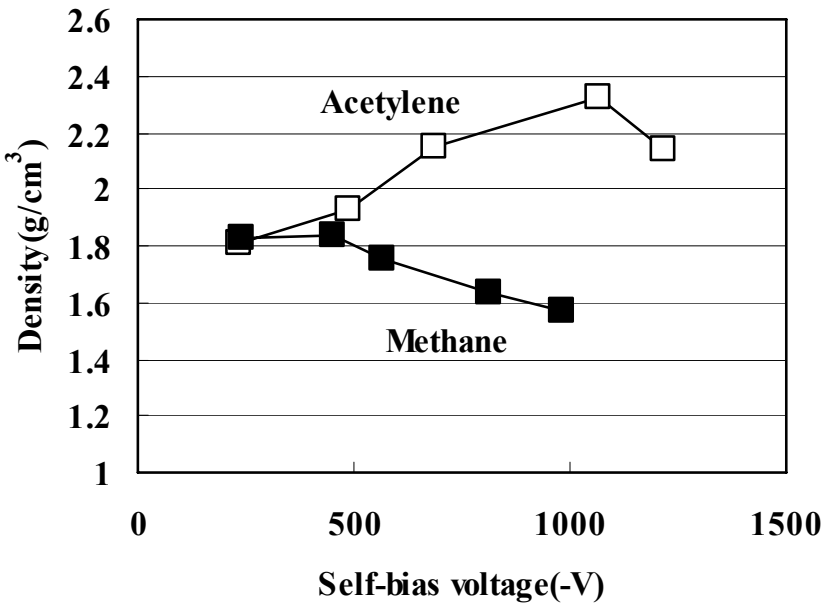

Fig. 6 Dependence of density on self-bias voltage

疎な構造になることを示唆している。アセチレン原料の場合は 自己バイアス電圧と共に増加し、- $1000 \mathrm{~V}$ 付近で最大值を示し た。アセチレン原料ではメタン原料より緻密な膜になることを 示唆している。

\section{3 ラマン分光測定による $I_{\mathrm{D}} / I_{\mathrm{G}}$}

Fig.7 にメタン原料、Fig.8 にアセチレン原料D L C膜のラマ

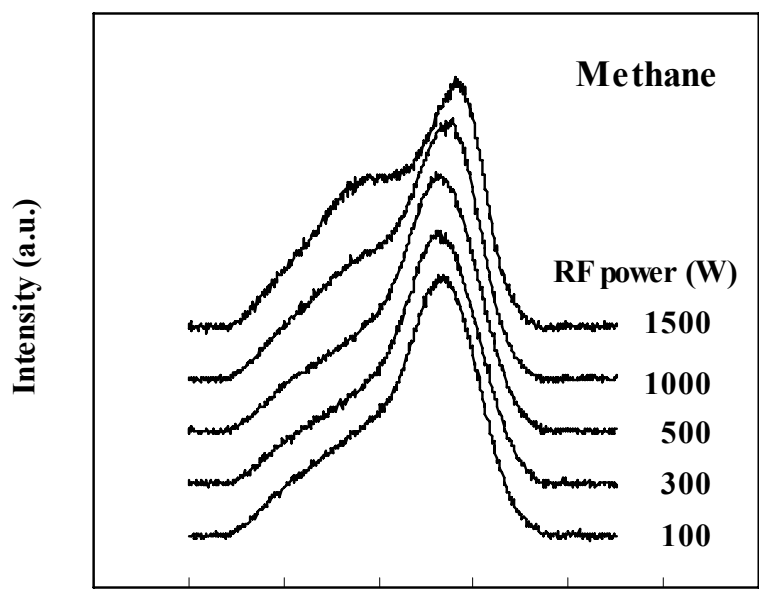

$\begin{array}{llllllll}800 & 1000 & 1200 & 1400 & 1600 & 1800 & 2000 & 2200\end{array}$

Raman shift $\left(\mathrm{cm}^{-1}\right)$

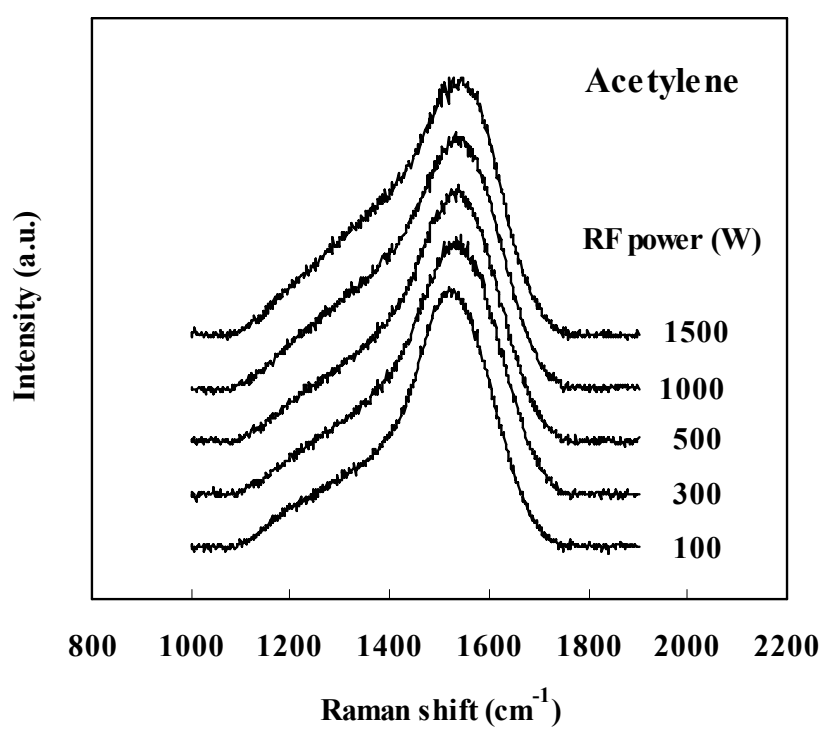

Fig.8 Raman spectra of DLC films from acetylene

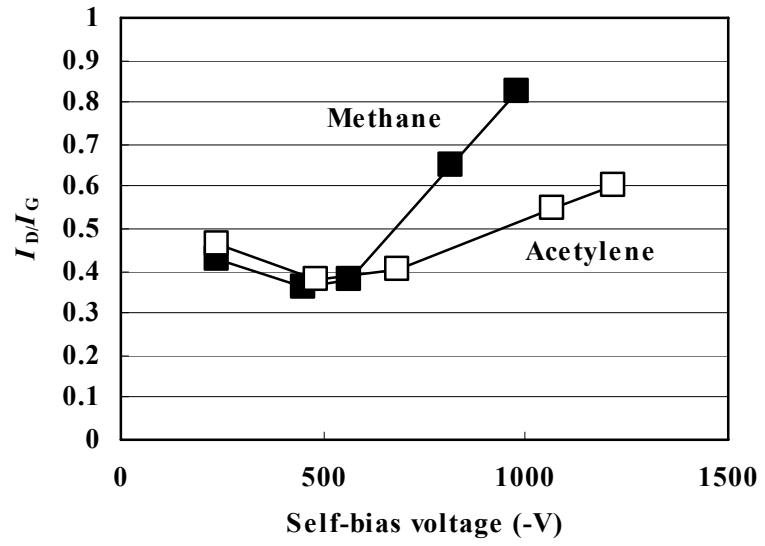

Fig. 9 Dependence of $I_{\mathrm{D}} / I_{\mathrm{G}}$ on RF power

ンスペクトルを示す。いずれも R F パワーの増加と共にDピー ク強度が増加している。これはR Fパワーの増加と共に負の自 己バイアス電圧が増加し、正イオンの基板に対する衝突エネル ギ一の増加と共にグラファイト結合が増加していることを示 している。ラマンスペクトルのDピークとGピークとの強度比 $I_{\mathrm{D}} / I_{\mathrm{G}}$ の自己バイアス電圧依存性をFig.9 に示す。メタン原料、ア セチレン原料いずれの場合も自己バイアス電圧が増加するに つれて $I_{\mathrm{D}} / I_{\mathrm{G}}$ は増加する。これは高い 衝突エネルギーによる成膜 でDLC膜の非晶質性が高くなることを示す。また、アセチレン 原料よりメタン原料の方が $I_{\mathrm{D}} I_{\mathrm{G}}$ が大になり、より非晶質性が高 くなることを示している。

\section{4 交流温度からの熱伝導率の算出}

Fig. 10 に $\mathrm{Si}$ 基板上 DLC 膜の交流温度の実験值と $\mathrm{Si}$ ウェハ 


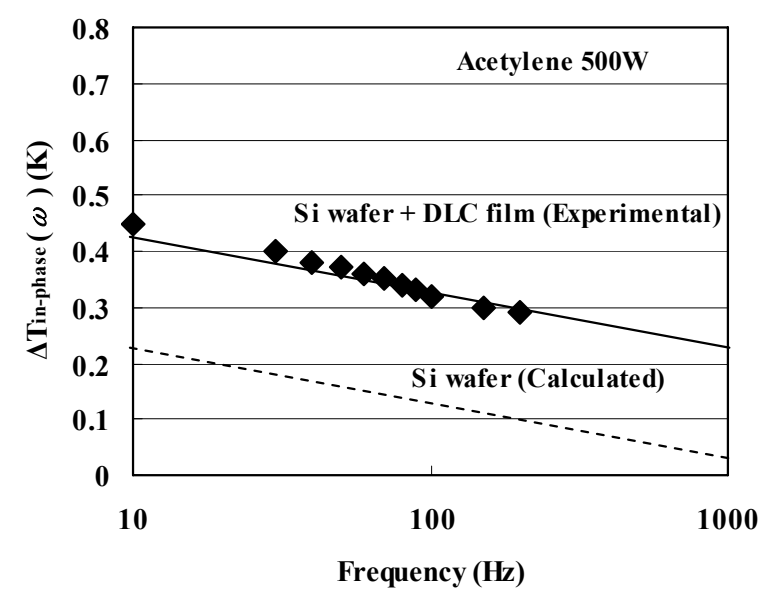

Ftg.10 Dependence of alternating temperature on frequency

一の計算値との差から熱伝導率度率を算出寸る場合の一例を 示寸。基板の交流温度の周波数依存性は文献值より求めた。

\section{5 熱伝導率の成膜条件（自己バイアス電圧）依存性}

Fig. 11 に熱伝導率の成膜条件依存性として、自己バイアス電 圧依存性を示寸。アセチレン原料の場合は自己バイアス電圧と 共に熱伝導率が増加、一 $680 \mathrm{~V}$ において最大值 $2.1 \mathrm{~W} / \mathrm{mK}$ を示し、 自己バイアス電圧がさらに増加寸ると熱伝導率は減少した。メ タン原料の場合は最大值が $1.4 \mathrm{~W} / \mathrm{mK}$ であり、自己バイアス電 圧依存性は顕著ではなかった。本研究における熱伝導率は膜厚 の測定精度などを考慮すると約 $\pm 20 \%$ 程度と見積もられる。熱 伝導率に影響を及ぼす DLC 膜の構造的な要因について以下で 考察する。

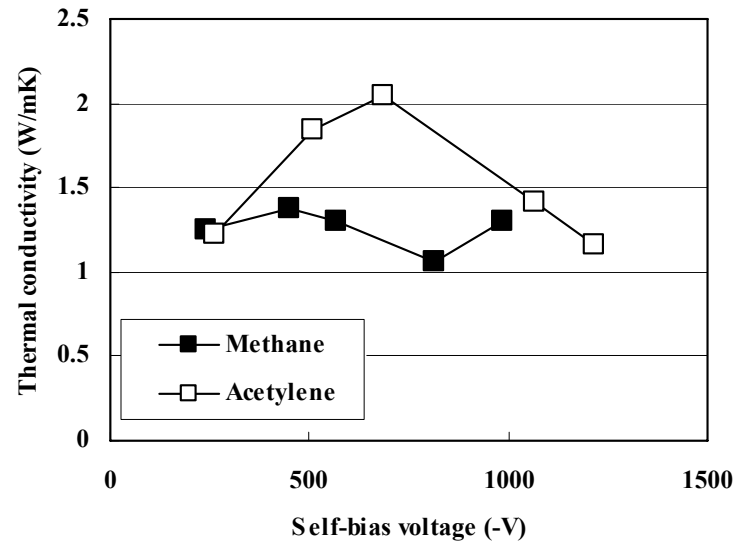

Fig. 11 Dependence of thermal conductivity on self-bias voltage

\section{6 熱伝導率の密度、 $I_{\mathrm{D}} / I_{\mathrm{G}}$ 依存性}

Fig. 12 に熱伝導率の密度依存性を示寸。メタン原料の場合、
熱伝導率の密度依存性は顕著ではなかった。アセチレン原料の 場合、密度が $1.8 \mathrm{~g} / \mathrm{cm}^{3}$ から $2.1 \mathrm{~g} / \mathrm{cm}^{3}$ への 1.2 倍の増加に対して 熱伝導率は $1.2 \mathrm{~W} / \mathrm{mK}$ から $2.1 \mathrm{~W} / \mathrm{mK}$ へ 1.5 倍増加し、最大值を 示した。自己バイアス電圧がー240Vから－680Vへの変化に対 応し、水素の脱離による密度の増加溔伝導率の増加に寄与し たと考えられる。さらなる自己バイアス電圧の増加により密度

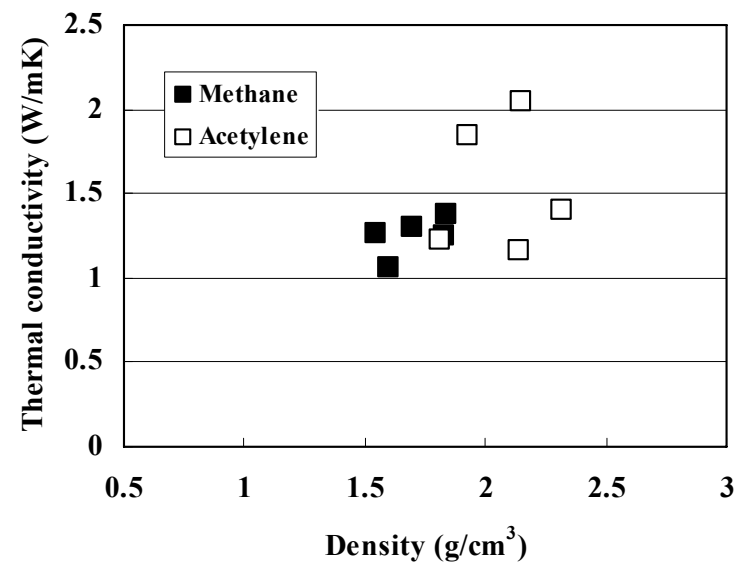

Fig.12 Dependence of thermal conductivity on density

が $2.3 \mathrm{~g} / \mathrm{cm}^{3}$ へ増加しても熱伝導率は $1.4 \mathrm{~W} / \mathrm{mK}$ に減少し、密 度の増加が熱伝導率の増加に繋がらなかった。これは一 680V以上の自己バイアス電圧の増加に対してFig.9 に示寸 ように $I_{\mathrm{D}} / I_{\mathrm{G}}$ が増加し、非晶質性が増加するためと考えられる。 すなわち非晶質性が大きくなると熱伝導率は密度依存性を 示さなくなることを示す。Fig. 13 に熱伝導率の非晶質性 $I_{\mathrm{D}} / I_{\mathrm{G}}$ 依存性を示寸。メタン原料の場合は熱伝導率が $I_{\mathrm{D}} / I_{\mathrm{G}}$

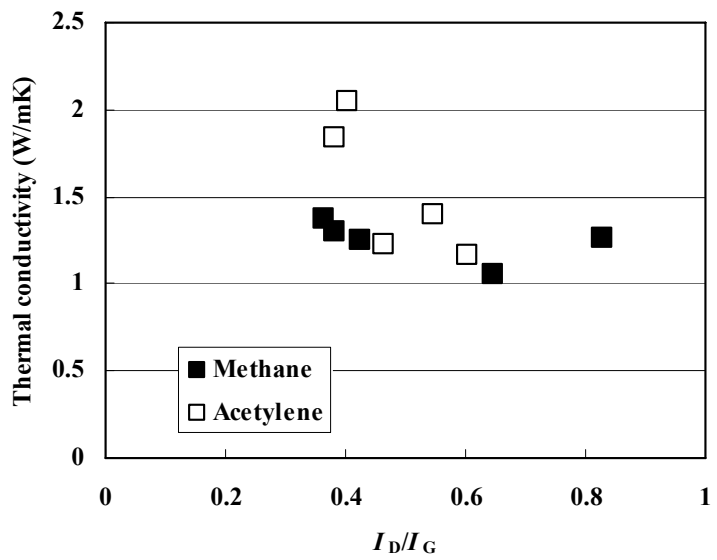

Fig.13 Dependence of thermal conductivity on $I_{\mathrm{D}} / I_{\mathrm{G}}$

メタン原料の場合は熱伝導率が $I_{\mathrm{D}} / I_{\mathrm{G}}$ と共に減少する傾向があ るが、顕著な依存性は示さなかった。アセチレン原料の場合は 
熱伝導率が $I_{\mathrm{D}} / I_{\mathrm{G}}$ の増加と共に大きく減少した。これにより、密 度が高く、水素濃度が低くとも熱伝導率が低い原因は非晶質性 $I_{\mathrm{D}} / I_{\mathrm{G}}$ が増加することによると推察される。

\subsection{DLC 膜の熱伝導率と膜構造との関係}

Table1 にメタン原料とアセチレン原料の DLC 膜の熱伝導率 がそれぞれ最大になる成膜条件における特性值の比較を示す。 アセチレン原料はメタン原料の 1.5 倍の熱伝導率が得られた。 前述のように、 $I_{\mathrm{D}} / I_{\mathrm{G}}$ は $L \mathrm{a}^{2}$ に比例するとされるので、メタン原 料、アセチレン原料それぞれについて熱伝導率が最大值を示す $I_{\mathrm{D}} / I_{\mathrm{G}}$ は 0.38 及び 0.4 とほぼ同等で、Laは約 $0.8 \mathrm{~nm}$ と算出される。 いずれもグラファイト結合クラスターの熱伝導率は同等と考 えられるので、DLC膜全体としての熱伝導率の差は水素濃度及 ひ密度の差に依存し、水素濃度が低く、密度が高いアセチレン 原料の方がメタン原料より熱伝導率が高い值が得られたと考 えられる。アセチレン原料のLaが大きくなることにより熱伝導 率が低下したのは、非晶質物質の熱伝導メカニズムがフォノン による波動ではなく、フォノンの波長の $1 / 2$ の大きさの局在化 した減衰振動子によるとしたCahill一Pohlモデル[4]により説明 されると考えるが、詳細な検討は今後の課題である。

Table 1 Comparison of structural parameters for DLC films

\begin{tabular}{lcc}
\hline & Methane & Acetylene \\
\hline Thermal conductivity $(\mathrm{W} / \mathrm{mK})$ & 1.4 & 2.1 \\
$I_{\mathrm{D}} / I_{\mathrm{G}}$ & 0.38 & 0.40 \\
Hydrogen content (at. \%) & 38.0 & 27.0 \\
Density $\left(\mathrm{g} / \mathrm{cm}^{3}\right)$ & 1.84 & 2.15 \\
\hline
\end{tabular}

\section{4. 結論}

$\mathrm{RF}$ プラズマ CVD により成膜した DLC 膜の熱伝導率を $3 \omega$ 法により測定した結果、最大值はアセチレン原料の場合では $2.1 \mathrm{~W} / \mathrm{mK}$ 、メタン原料では $1.4 \mathrm{~W} / \mathrm{mK}$ であった。メタン原料の 場合は膜中水素濃度が大きいため、熱伝導率は自己バイアス電 圧、密度及び $I_{\mathrm{D}} I_{\mathrm{G}}$ に対する依存性が顕著ではなかった。一方、 アセチレン原料の場合は非晶質性が低い成膜条件では熱伝導 率は密度依存性を示し、非晶質性が高くなる成膜条件では密度 が高くとも熱伝導率が低く、密度依存性を示さなかった。い゙

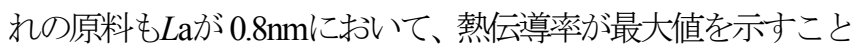
が分かった。

\section{NOMENCLATURE}

$I_{\mathrm{D}} \quad$ : Intensity of D-peak

$I_{\mathrm{G}} \quad$ : Intensity of G-peak

$\Delta T(\omega)$ : Temperature oscillation of metal line, $\mathrm{K}$

$P \quad: \quad$ Power density applied on to metal line, $\mathrm{W} / \mathrm{m}$

$\lambda_{\mathrm{s}} \quad$ : Thermal conductivity of substrate, $\mathrm{W} / \mathrm{mK}$

$D_{\mathrm{s}} \quad:$ Thermal diffusivity of substrate, $\mathrm{W} / \mathrm{m}^{2} \mathrm{~K}$

$2 b \quad$ : Width of metal line, $\mathrm{m}$

$d_{\mathrm{f}} \quad$ : Thickness of thin film, $\mathrm{m}$

a : Slope of the plots of $\Delta T_{\text {in-phase }}(\omega) \quad$ vs. $\ln (\omega)$

$\lambda_{\mathrm{f}} \quad:$ Thermal conductivity of thin film, $\mathrm{W} / \mathrm{mK}$

$\Delta T_{\mathrm{s}+\mathrm{f}} \quad$ : Temperature oscillation of substrate and film, $\mathrm{K}$

$\Delta T_{s} \quad$ : Temperature oscillation of substrate, $\mathrm{K}$

$I_{0} \quad$ : Supplied amplitude of alternating current, A

$R_{0} \quad$ : Resistance of metal line, $\Omega$

$\alpha \quad$ : Coefficient of resistivity of metal line

$V(t)$ : Alternating voltage between metal line, $\mathrm{V}$

$V_{3 \omega} \quad:$ Third-harmonic voltage drop across metal line, $\mathrm{V}$

La $\quad$ : Cluster size of graphite bonds, $\mathrm{nm}$

\section{参考文献}

[1] J. Robertson, Mat. Sci. Eng., R37 (2002) 129-281

[2] J. Diaz, G Paolicelli, S. Ferrer, F. Comin, Phys. Rev. B, 54 (1996) 8064-8069

[3] P. Merel, M. Tabbal, M. Chaker, S. Moisa, Appl. Surf. Sci., 136 (1998) 105-110

[4] J. Bodzenta, Chaos ,Solitons \& Fractals , 10 (1999) 2087-2098

[5] G. Chen P. Hui, S. Xu, Thin Solid Films, 366 (2000) 95-99

[6]A. J. Bullen K.E. O’Hara, D.G Cahill, J. Appl. Phys, 88 (2000) 6317-6320

[7] H.Kakiuchi, T. Kobayashi, T. Terai, Nucl. Instrum. and Methods in Phys. Res. B, 166-167 (2000) 415-419

[8] 山根常幸, 金属, Vol.70, 10 (2000) 889-893

[9] D.G. Cahill, Rev. Sci. Instrum., 61 (1990) 802-808

[10] D.G Cahill, M.Katiyar, J. R. A. Abelson, Phys. Rev. B, 50 (1994) 6077-6081

[11] S.-M.Lee, D.G. Cahill, J. Appl. Phys., 81 (1997) 2590-2595

[12] J.H. Kim, A. Feldman, D. Novolonty, J. Appl. Phys., 86 (1999) 3959-3963

[13］山根常幸他; 第20 回日本熱物性シンポジウム講演論文 集(東京, 1999)

[Received Mar. 28, 2007, Accepted June 11, 2007] 